\title{
The role of inhaled corticosteroids in children with asthma
}

\author{
John Price
}

\begin{abstract}
Inhaled corticosteroids offer a wide range of anti-inflammatory activity and have consistently proved to be the most effective medication for the control of childhood asthma. The high efficacy of inhaled corticosteroids has led to their use in milder disease and younger children in the hope that permanent changes in lung function and airway remodelling may be prevented. However, evidence has emerged over the past six years that the first of the inhaled corticosteroids to become available, beclomethasone dipropionate, may cause growth deceleration at a dose of $400 \mu \mathrm{g}$ per day. This is especially apparent in children with mild symptoms. The newest of the inhaled corticosteroids to be developed, fluticasone propionate, is equipotent to older compounds at half the dose and in low doses is superior in efficacy to sodium cromoglycate. Two recent studies have shown that fluticasone propionate 100-200 $\mu \mathrm{g}$ per day does not cause growth suppression in children with mild asthma. The long term outcome for children who wheeze in early life is difficult to predict. For this reason the use of inhaled corticosteroids in very young children is best reserved for those with severe symptoms or a strong family history of asthma, and evidence, from measurement of inflammatory markers, of airway inflammation.

(Arch Dis Child 2000;82(Suppl II):ii10-ii14)
\end{abstract}

Keywords: asthma; inhaled corticosteroids; growth velocity; wheeze

Inhaled corticosteroids were introduced in 1973 as an alternative to the oral formulation for the treatment of children with moderate or severe asthma. ${ }^{1}$ Evidence indicates that the frequency of asthma symptoms and the number of exacerbations are reduced, and lung function and the quality of life are improved following treatment with inhaled corticosteroids. ${ }^{1}$

A total of 23311 asthma deaths were registered in England and Wales between 1983

Department of Child Health, King's College, University of London, UK

J Price

Correspondence to: Professor J Price, Department of Child Health, King's College Hospital,

Denmark Hill, London

SE5 8RX, UK

email: john.price@kcl.ac.uk mild and persistent childhood asthma. ${ }^{3-5}$ However, concerns remain regarding the long term side effects of inhaled corticosteroids, such as beclomethasone dipropionate, on the hypothalamic-pituitary-adrenal axis and childhood growth rates. ${ }^{6}$

This paper reviews the evidence of the efficacy of inhaled corticosteroid therapies for the treatment of childhood asthma and the risk of growth suppression as an adverse event.

\section{Efficacy}

The increased use of inhaled corticosteroids is based on the superior efficacy of these agents compared with sodium cromoglycate. Although this is well established in adults there are few published studies comparing the efficacy of inhaled corticosteroids with sodium cromoglycate in children. Price and Weller ${ }^{7}$ compared the efficacy of inhaled fluticasone propionate $(50 \mu \mathrm{g}$ twice daily) with that of sodium cromoglycate ( $20 \mathrm{mg}$ four times a day) over eight weeks in 225 asthmatic children aged 4-12 years, who had not previously been treated with inhaled corticosteroids or sodium cromoglycate. Although both treatments improved forced expiratory volume $\left(\mathrm{FEV}_{1}\right)$ and peak expiratory flow (PEF) compared with baseline, fluticasone propionate significantly improved both morning $(p=0.0001)$ and evening PEF ( $p=0.0011$ ), but not $\mathrm{FEV}_{1}$ compared with sodium cromoglycate. The effect of fluticasone propionate was apparent after only 1-2 weeks of treatment (fig 1). Fluticasone propionate was more effective than sodium cromoglycate $(p<0.05)$ in terms of the proportion of symptom free days and nights. Fluticasone propionate also showed a superior safety profile, and thus had a better risk to benefit ratio than sodium cromoglycate in this study. It is necessary to give inhaled steroids twice daily to achieve asthma control, but a once a day regimen is as effective as twice daily when treating stable, mild to moderate asthma in children. ${ }^{8}$

\section{Tolerability}

SHORT TERM GROWTH KNEMOMETRY

Various studies have examined the effect of inhaled budesonide, fluticasone propionate, and beclomethasone dipropionate on short term growth of the lower leg in asthmatic children, assessed by knemometry.

Low dose budesonide does not suppress growth in asthmatic children. Although budesonide $(200 \mu \mathrm{g}, 400 \mu \mathrm{g}$, and $800 \mu \mathrm{g}$ daily) dose dependently reduced growth velocity in one study, this only reached statistical significance with the highest dose. ${ }^{9}{ }^{10}$ Wolthers and Pedersen ${ }^{11}$ reported that neither budesonide the proven advantages of corticosteroids be used for the treatment of 


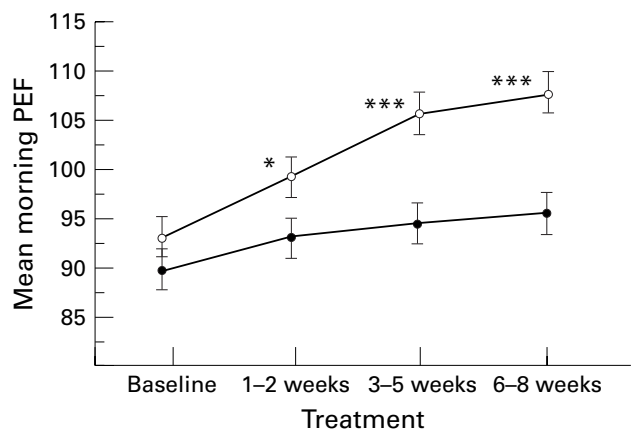

Figure 1 Comparative efficacy of fluticasone propionate $100 \mu \mathrm{g} /$ day and sodium cromoglycate $80 \mathrm{mg} /$ day taken for eight weeks in 225 asthmatic children aged 4-12 years. Open and closed circles depict fluticasone propionate and sodium cromoglycate respectively. ${ }^{\star} p<0.05$;

$\star \star \star p ~=0.001$. Reprinted by permission of $W B$ Saunders Company.'

$200 \mu \mathrm{g}$ nor $400 \mu \mathrm{g}$ daily administered via Turbuhaler reduced growth velocity in 37 asthmatic children. Two further studies confirmed that budesonide $800 \mu \mathrm{g} /$ day but not $200 \mu \mathrm{g} /$ day impaired growth. ${ }^{12}{ }^{13}$ Bisgaard observed a $50 \%$ reduction in growth velocity with budesonide $800 \mu \mathrm{g} /$ day administered for four weeks compared with placebo in 18 toddlers. ${ }^{12}$

One dose-response study which compared the effects of two doses of fluticasone propionate $200 \mu \mathrm{g}$ and $400 \mu \mathrm{g}$ daily (administered via Diskhaler), budesonide $200 \mu \mathrm{g}$ and $400 \mu \mathrm{g}$ daily (via Turbuhaler), or placebo on lower leg growth rates in 48 asthmatic children aged 6-12 years, showed that only those children treated with budesonide $400 \mu \mathrm{g}$ daily had lower growth rates than placebo treated children after two weeks of treatment. ${ }^{14}$

One study that compared beclomethasone dipropionate $400 \mu \mathrm{g}$ and $800 \mu \mathrm{g}$ daily and fluticasone propionate $200 \mu \mathrm{g}$ daily showed that both doses of beclomethasone dipropionate impaired growth, whereas fluticasone propionate did not. ${ }^{15}$

LONG TERM GROWTH VELOCITY-

BECLOMETHASONE DIPROPIONATE

Four randomised controlled trials have reported that beclomethasone dipropionate 400 $\mu \mathrm{g} /$ day slows growth velocity by approximately $1-1.5 \mathrm{~cm}$ per year. ${ }^{16-19}$

The first ${ }^{16}$ compared beclomethasone dipropionate with theophylline in children aged 6-16 years with asthma ranging from mild to moderately severe. Asthma control was better in children treated with inhaled steroid but growth was slower than in those treated with theophylline. The wide age range raises the possibility that age of onset of puberty was a confounding variable.

Doull and colleagues ${ }^{17}$ noted that 94 children with infrequent wheezing associated with viral infection treated with beclomethasone dipropionate $400 \mu \mathrm{g}$ daily via Diskhaler for seven months had grown by a mean of $1 \mathrm{~cm}$ less than children who received placebo treatment $(2.66 v 3.66 \mathrm{~cm} ; \mathrm{p}<0.001)$. In this study beclomethasone dipropionate had no therapeutic benefit on mild intermittent virus associated wheezing. ${ }^{20}$ Furthermore, beclo-

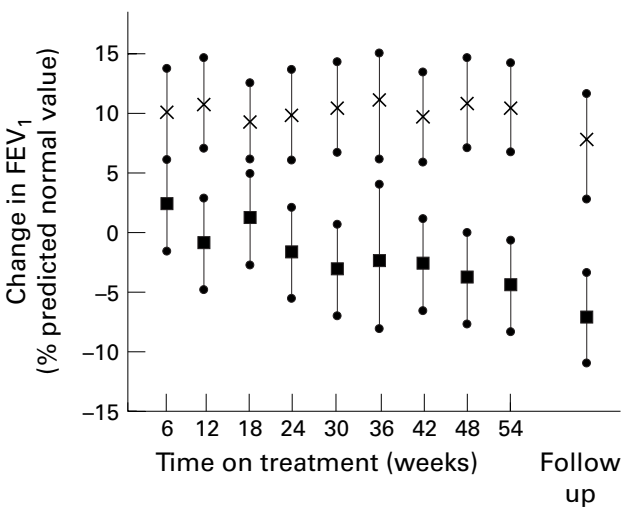

Figure 2 Effect of treatment with either beclomethasone dipropionate $400 \mu \mathrm{g} /$ day (crosses) or salmeterol $100 \mu \mathrm{g} /$ day (closed squares) for one year on FEV in 67 asthmatic children aged 6-16 years. Reproduced with permission. ${ }^{19}$

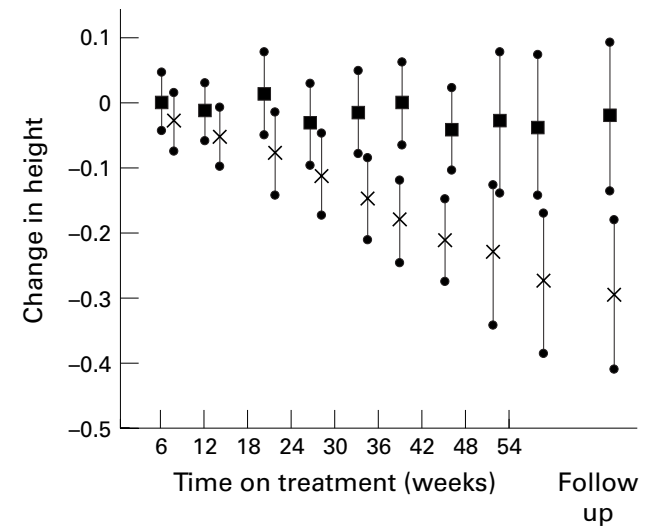

Figure 3 Effect of treatment with either beclomethasone dipropionate $400 \mu \mathrm{g} /$ day (crosses) or salmeterol $100 \mu \mathrm{g} /$ day (closed squares) for one year on height change in 67 asthmatic children aged 6-16 years. Reproduced with permission. ${ }^{19}$

methasone dipropionate treated patients remained significantly shorter than placebo treated patients at the end of the study (4.72 $v$ $5.56 \mathrm{~cm} ; \mathrm{p}=0.0004$ ).

Simons ${ }^{18}$ evaluated the efficacy of beclomethasone dipropionate $400 \mu \mathrm{g} /$ day, salmeterol $50 \mu \mathrm{g}$ twice daily, and placebo over one year in 241 children aged 6-14 years with persistent asthma. Beclomethasone dipropionate treated patients grew significantly less $(3.96 \mathrm{~cm})$ than those in the placebo $(5.04 \mathrm{~cm} ; \mathrm{p}=0.018)$ and salmeterol $(5.4 \mathrm{~cm} ; \mathrm{p}=0.004)$ groups.

Verberne and colleagues ${ }^{19}$ compared the effects of long term administration of either salmeterol $100 \mu \mathrm{g} /$ day or beclomethasone dipropionate $400 \mu \mathrm{g} /$ day in 67 asthmatic children aged 6-16 years. After one year, asthma control and lung function were better (fig 2) in the beclomethasone dipropionate treated patients, but they had grown significantly less than salmeterol patients (4.7 $v 6.1 \mathrm{~cm} ; \mathrm{p}=0.007)$. Height was also expressed as the height standard deviation score (beclomethasone dipropionate group $-0.03 v$ salmeterol group -0.28 at 54 weeks; $\mathrm{p}=0.001$; fig 3 ).

In contrast to these studies, Silverstein and colleagues $^{21}$ studied 153 children whose mean age at the onset of asthma was 6 years and who had taken corticosteroids for an average of seven years, and reported that inhaled cortico- 
steroids did not affect the final height attained in adulthood. Corticosteroid treated boys and girls achieved heights of $178.1 \mathrm{~cm}$ at 19 years and $166.3 \mathrm{~cm}$ at 17 years, respectively, compared with average heights of $179.7 \mathrm{~cm}$ and $165.6 \mathrm{~cm}$ for boys and girls respectively in those who had not taken corticosteroids. Another study recently reported a similar absence of effect of inhaled corticosteroids on final height. ${ }^{22}$

There are several possible explanations for this apparent lack of consistency between growth velocity and final height following long term beclomethasone dipropionate treatment.

- The first possible explanation pertains to the time period during which these children were enrolled-that is, from 1964 to 1983 . During this time, glucocorticoid treatment of asthma was changing: in the 1960s and 1970s, low dose oral corticosteroids were only prescribed to patients with severe asthma, whereas inhaled corticosteroids have been commonly prescribed since the 1980 s; compared with inhaled therapy, oral steroid treatment is associated with growth impairment. ${ }^{23}$ McCowan and colleagues ${ }^{24}$ reported that children who had mild to moderate symptoms of asthma grew normally (mean female and male adult heights were 165.6 (6.0) and 179.7 (6.8) $\mathrm{cm}$ respectively), while those who had severe symptoms and who were treated with high doses of corticosteroids, were significantly shorter (mean female and male adult heights were 166.3 (6.4) and $178.1(7.3) \mathrm{cm}$ respectively).

- Variable compliance and/or noncompliance may be a factor as seen by "growth catch up" when children become symptom free and stop taking their medication. One study of compliance revealed that according to daily diaries, 95\% of patients used inhaled corticosteroids as prescribed; however, investigators found the actual use to be $60 \%$, with only approximately $30 \%$ of doses taken at the correct time. ${ }^{25}$

- A third possible reason may involve the lack of dose reduction once optimum control of asthma is achieved in randomised controlled trials. For example, in the study of Verberne and colleagues, ${ }^{19}$ the $\mathrm{FEV}_{1}$ in beclomethasone treated patients had improved substantially after three months and many children had become symptom free. In clinical practice, this would be an indication to halve the dose of inhaled steroid.

LONG TERM GROWTH VELOCITY-FLUTICASONE PROPIONATE

One study, which compared the effects of fluticasone propionate $100 \mu \mathrm{g} /$ day with sodium cromoglycate $80 \mathrm{mg} /$ day on growth in asthmatic children over a year, reported similar height and height velocity standard deviations following treatment, indicating that neither fluticasone propionate $(6.0(0.1) \mathrm{cm})$ nor

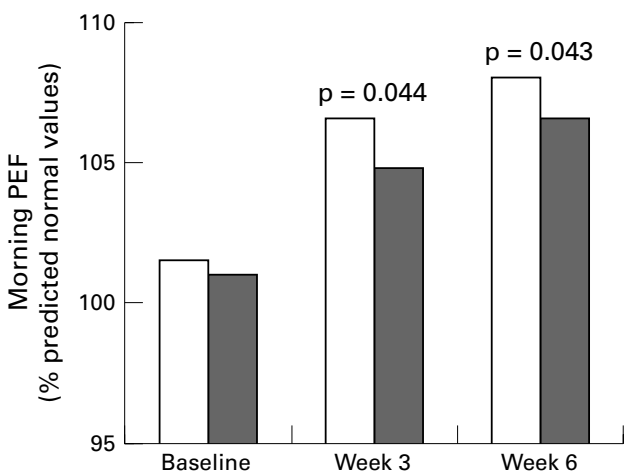

Figure 4 Effect of fluticasone propionate $200 \mu \mathrm{g} /$ day compared with beclomethasone dipropionate $400 \mu \mathrm{g} /$ day on lung function in asthmatic children over six weeks. Open and hatched columns depict fluticasone propionate and beclomethasone dipropionate respectively. Reprinted with permission from the BMF Publishing Group. ${ }^{27}$

sodium cromoglycate $(6.5(0.5) \mathrm{cm})$ caused growth retardation. ${ }^{26}$

Furthermore, Allen and colleagues ${ }^{23}$ observed that treatment with fluticasone propionate $100 \mu \mathrm{g} /$ day or $200 \mu \mathrm{g} /$ day for one year did not significantly reduce growth rates in 325 asthmatic children compared with placebo. Fluticasone propionate $200 \mu \mathrm{g} / \mathrm{day}$ is at least as effective as beclomethasone dipropionate $400 \mu \mathrm{g} /$ day in the treatment of mild to moderate childhood asthma. In one study, fluticasone propionate $200 \mu \mathrm{g} /$ day taken for six weeks improved morning PEF over baseline to a slightly greater extent than beclomethasone dipropionate $400 \mu \mathrm{g} / \mathrm{day}$ (fig 4 ) ${ }^{27}$ Rao and colleagues ${ }^{6}$ compared growth rates in children with moderately severe asthma aged $5-10$ years receiving either beclomethasone dipropionate $400 \mu \mathrm{g} /$ day or fluticasone propionate 200 $\mu \mathrm{g} /$ day. Growth velocity in the children receiving fluticasone propionate $(5.75 \mathrm{~cm} /$ year$)$ was significantly greater than in the children receiving beclomethasone dipropionate (fig 5) ${ }^{6}$ Likewise, De Benedictis and colleagues ${ }^{28}$ observed a significantly lower growth velocity in children treated with beclomethasone dipropionate $400 \mu \mathrm{g} /$ day for a year $(4.09 \mathrm{~cm} /$ year $)$ compared with those who received fluticasone propionate $400 \mu \mathrm{g} /$ day $(4.09 \approx 4.99 \mathrm{~cm} /$ year; $\mathrm{p}<0.001)$.

\section{BONE DENSITY}

Several cross sectional or short term longitudinal studies which evaluated the effect of inhaled corticosteroids on bone metabolism have indicated that treatment does not affect bone density. One longitudinal study showed that bone density was similar in 51 patients treated with either low ( $\leqslant 500 \mu \mathrm{g} /$ day $)$ or high (>800 $\mu \mathrm{g} /$ day) dose budesonide or beclomethasone dipropionate for three years and that bone density remained constant throughout the study. ${ }^{29}$ However, this study was conducted in adults and too few longitudinal studies have been conducted in asthmatic children to draw any conclusions on the long term effects of inhaled corticosteroids on bone metabolism in children. Two studies in which 83 children with asthma inhaled beclomethasone dipropionate $(<300 \mu \mathrm{g} /$ day $)$ for six or seven months 


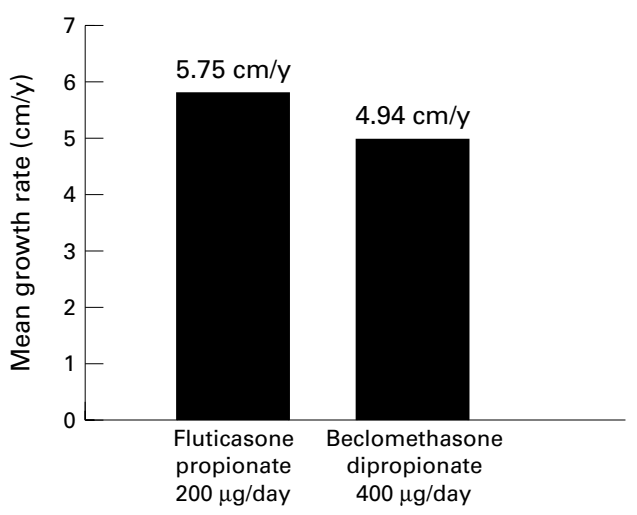

Figure 5 Mean growth rate in 23 corticosteroid naïve children with severe asthma aged 5-10 years treated with fluticasone propionate and beclomethasone dipropionate. (Between group difference: $0.81 \mathrm{~cm} / y$; 95\% CI: 0.45-1.16 cm/y.) From Rao et al. ${ }^{6}$

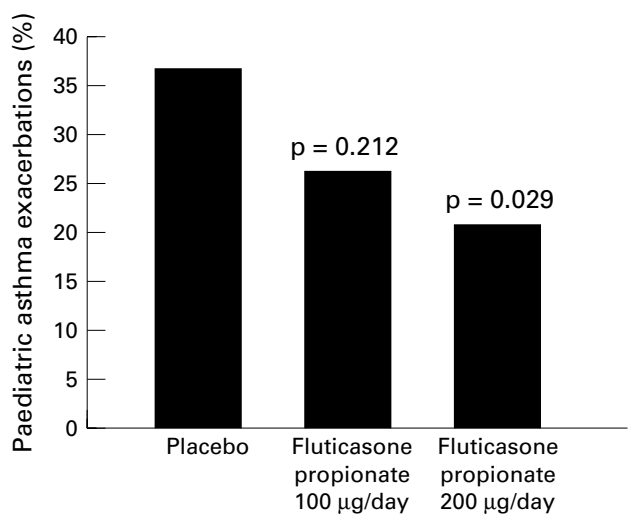

Figure 6 Effect of fluticasone propionate propionate 100 $\mu \mathrm{g} /$ day and $200 \mu \mathrm{g} /$ day, compared with placebo on the incidence of exacerbations of asthma in children.

Reproduced with permission.

showed that bone mineral density was not altered. $^{3031}$ Furthermore, corticosteroid administration for 16 months did not alter bone density in 21 children with moderate to severe asthma. $^{32}$

\section{Inhaled corticosteroids in preschool children}

Over the past decade, more than 20 studies have examined the efficacy of inhaled corticosteroids in preschool asthmatic children. Studies in children over the age of 2 years with moderate to severe persistent symptoms have consistently shown a beneficial effect. ${ }^{33}$ Little or no benefit is seen in those with episodic viral wheeze. ${ }^{34}$ In children under the age of 2 years, the results of the clinical trials with inhaled steroids have given variable and inconsistent results. Bisgaard and colleagues ${ }^{35}$ recently showed that inhaled fluticasone propionate via the Babyhaler spacer achieved good control of symptoms in children aged 1-4 years with moderate asthma. Fluticasone propionate 200 $\mu \mathrm{g} /$ day also significantly reduced the number of asthma exacerbations compared with placebo (fig 6). However, the dilemma of which patients to treat remains.

Martinez and colleagues ${ }^{36}$ conducted a prospective study of wheezing during the first six years of life in a group of over 1000 children. A third of these children developed wheezing illness during the first three years, of which $40 \%$ were still wheezing at the age of 6 years and many had developed lung function abnormalities. However, the other $60 \%$ had become symptom free. Thus, if all were treated in the first three years with inhaled steroids $60 \%$ would be treated unnecessarily. On the other hand, if none were treated the opportunity to prevent lung function abnormalities in some would be lost.

Examination of the risk factors associated with asthma may help to define which children to treat. Parental asthma, particularly if both parents are affected, is a significant risk factor (40\%), although it only accounts for $0.3 \%$ of the persistent wheezing child population. ${ }^{37}$ The presence or absence of parental atopy is also a frequently reported risk factor; if one parent is affected the risk is $19 \%$ whereas if neither are affected the risk falls to $13 \%$. However, many children who develop persistent wheezing do not have a parental history of asthma or atopy. To date, there are no established guidelines regarding which patients to treat. However, it is logical to treat preschool children who exhibit frequent persistent symptoms, severe exacerbations, or who have clinical evidence of lung hyperinflation between attacks. A lower threshold to introduce inhaled steroid treatment should be applied to those with a personal or family history of atopy or increased concentrations of eosinophil cationic protein.

\section{Conclusions}

The data presented within this review show that inhaled corticosteroids effectively manage childhood asthma by improving symptom control and lung function. However, at recommended doses some, but not all, corticosteroids may be associated with growth retardation in asthmatic children.

Many children who experience wheezing during their early childhood outgrow their symptoms. Those who experience severe wheezing are more likely to have persistent symptoms. Thus preschool children who experience frequent exacerbations or who have frequent and persistent or severe wheezing should be treated with inhaled steroids.

Inhaled corticosteroids are recommended for the treatment of persistent asthma of all severities in school age children, but the lowest possible effective dose should be used. ${ }^{3-5}$ When high doses of inhaled corticosteroids are necessary, the clinical benefits must be balanced against the possibility of growth retardation. Patient growth should be carefully monitored and the dose reduced according to symptom improvement.

Beclomethasone dipropionate at a dose of $400 \mu \mathrm{g} /$ day may cause growth deceleration, particularly if used in children with mild asthma. On the other hand fluticasone propionate at recommended doses (100-200 $\mu \mathrm{g} /$ day) does not retard growth and is at least as effective as other therapeutic options.

\footnotetext{
1 Price JF. Asthma, growth and inhaled corticosteroids. Respir Med 1993;87 (suppl A):23-6.

Campbell MJ, Cogman GR, Holgate ST, Johnston SC. AgeCampbell MJ, Cogman GR, Holgate ST, Johnston SC. Age-
specific trends in asthma mortality in England and Wales,
} 
1983-95: results of an observational study. BMf 1997;314: $1439-40$

3 NIH (National Institutes of Health). Global Initiative For Asthma. A pocket guide for asthma management and prevention 3659B. Bethesda, MD: NIH, 1998.

4 British guidelines on asthma management-1995 review and position statement. Thorax 1997;52:S1-20.

5 NIH (National Institutes of Health). Guidelines for the diagnosis and management of asthma. NIH Publication 97-4051. Bethesda, MD: NIH, 1997.

6 Rao R, Gregson RK, Jones AC, Miles EA, Campbell MJ, Warner JO. Systemic effects of inhaled corticosteroids on growth and bone turnover in childhood asthma: a comparison of fluticasone with beclomethasone. Eur Respir 71999 13:87-94.

7 Price JF, Weller PH. Comparison of fluticasone propionate and sodium cromoglycate for the treatment of childhood and sodium cromoglycate for the treatment of childhood
asthma (an open parallel group study). Respir Med asthma (an open

8 Hodges I, Netherway T. Once daily inhaled fluticasone propionate is as effective as twice daily in children with stable mild to moderate asthma. Thorax 1998;53(suppl 4):A55

9 Wolthers OD, Pedersen S. Growth of asthmatic children during treatment with budesonide: a double blind trial. BMF 1991;303:163-5.

10 Wolthers OD, Pedersen S. Controlled study of linear growth in asthmatic children during treatment with inhaled glucocorticosteroids. Pediatrics 1992;89:839-42.

11 Wolthers OD, Pedersen S. Knemometric assessment of systemic activity of once daily intranasal dry-powder budesonide in children. Allergy 1994;49:96-9.

12 Bisgaard H. Systemic activity of inhaled topical corticosteroid in toddlers studies by knemometry. Acta Paediatr 1993;82:1066-71.

13 Volovitz B, Amir J, Malik H, Kauschansky A, Varsano I. Growth and pituitary-adrenal function in children with severe asthma treated with inhaled budesonide. $N$ Engl f Med 1993;329:1703-8.

14 Agertoft L, Pedersen S. Short-term knemometry and urine cortisol excretion in children treated with fluticasone
propionate and budesonide: a dose response study. Eur propionate and budesonide:

15 Wolthers OD, Pedersen S. Short term growth during treatment with inhaled fluticasone propionate and beclomethasone dipropionate. Arch Dis Child 1993;68:673-6.

16 Tinkelman DG, Reed CE, Nelson HS, Offord KP. Aeroso beclomethasone dipropionate compound with theophylline as primary treatment of chronic, mild to moderately severe asthma in children. Pediatrics 1993;92:64-77.

17 Doull IJ, Freezer NJ, Holgate ST. Growth of prepubertal children with mild asthma treated with inhaled beclomethasone dipropionate. Am f Respir Crit Care Med 1995;151:1715-19.

18 Simons FER, on behalf of the Canadian Beclomethasone Dipropionate-Salmeterol Xinafoate Study Group. A comparison of beclomethasone dipropionate, salmeterol and placebo in children with asthma. N Engl f Med 1997;337: placebo in $1659-65$.

19 Verberne AAPH, Frost C, Roorda RJ, van der Laag H, Kerrebijn KF. One year treatment with salmeterol compared with beclomethasone dipropionate in children with with beclomethasone dipropionate in children

20 Doull IJ, Lampe FC, Smith S, Shreiber J, Freezer NJ, Holgate ST. Effect of inhaled corticosteroids on episodes of wheezing associated with viral infection in school age children: randomised double blind placebo controlled trial. BMF 1997;315:858-62.
21 Silverstein MD, Yunginger JW, Reed CE, O'Fallon WM. Attained adult height after childhood asthma: effect of gluocorticoid therapy. F Allergy Clin Immunol 1997;99:46674

22 Van Bever HP, Desager KN, Lijssens N, Weyler JJ, Du Caju MV. Does treatment of asthmatic children with inhaled corticosteroids affect their adult height? Pediatr Pulmonol 1999;27:369-75.

23 Allen DB, Bronsky EA, LaForce CF, et al. Growth in asthmatic children treated with fluticasone propionate. Fluticasone Propionate Asthma Study Group. If Pediatr 1998;132:472-7.

24 McCowan C, Neville RG, Thomas GE, et al. Effect of asthma and its treatment on growth: four year follow up of cohort of children from general practices in Tayside, Scotland. $B M \mathcal{F} 1998 ; 316: 668-72$.

25 Milgrem H, Bender B, Ackerson L, Bowry P, Smith B, Rand C. Noncompliance and treatment failure in children with asthma. F Allergy Clin Immunol 1996;98:1051-7.

26 Price JF, Russell G, Hindmarsh PC, Weller P, Heaf DP, Williams J. Growth during one year of treatment with futicasone propionate or sodium cromoglycate in children with asthma. Pediatr Pulmonol 1997;24:178-86.

27 Gustafsson P, Tsanakas J, Gold M, Primhak R, Radford M, Gillies E. Comparison of the efficacy and safety of inhaled fluticasone propionate $200 \mathrm{micrograms} /$ day with inhaled beclomethasone dipropionate 400 micrograms/day in mild and moderate asthma. Arch Dis Child 1993;69:206-11.

28 De Benedictis FM, Medley HV, Williams L. Long-term study to compare the safety and efficacy of fluticasone propionate and beclomethasone dipropionate in asthmatic children. Eur Respir f 1998;12(suppl 28):142.

29 Boulet L-P, Milot J, Gagnon L, Poubelle PE, Brown J. Long-term influence of inhaled corticosteroids on bone metabolism and density: are biological markers predictors of bone loss? Am ₹ Respir Crit Care Med 1999;159:838-44.

30 Inoue T, Doi S, Takamatsu I, et al. Effects of inhaled beclomethasone dipropionate on height, growth and bone metabolism in children with asthma. Arerugi 1995;44:67884.

31 Martinati LC, Bertoldo F, Gasperi E, Fortunati P, Lo Cascio V. Longitudinal evaluation of bone mass in asthmatic children treated with inhaled beclomethasone dipropionate or cromoglycate sodium. Allergy 1998;53:705-8.

32 Hopp RJ, Degan JA, Biven RE, Kinberg K, Gallagher GC. Longitudinal assessment of bone mineral density in children with chronic asthma. Ann Allergy Asthma Immunol 1995; 75:143-8.

33 Gleeson JGA, Price JF. Controlled trial of budesonide via the nebuhaler in pre-school asthma. BMF 1988;297:163-6.

34 Wilson N, Sloper K, Silverman M. Effect of continuous treatment with topical corticosteroid on episodic viral wheeze in pre-school children. Arch Dis Child 1995;72: 317-20.

35 Bisgaard H, Gillies J, Groenewald M, Maden C. The effect of inhaled fluticasone propionate in the treatment of young asthmatic children: a dose comparison study. Am f Respir Crit Care Med 1999;160:126-31.

36 Martinez FD, Wright AL, Taussig LM, Holberg CJ, Halonen M, Morgan WJ. Asthma and wheezing in the first six years of life. The Group Health Medical Associates. $N$ Engl f Med 1995;332:133-8.

37 Bergmann R, Woodcock A. Whole population or high-risk group? Eur Respir F 1998;12 (suppl 12):9s-12s. 